\title{
Nyt lys over Salmernes Bog, Kant, moderne kirkehistorie og samfundsdebat
}

Artiklerne i dette nummer af Dansk Teologisk Tidsskrift beskæftiger sig med et bredt spektrum af emner: Carsten Pallesen behandler to systematiske læsninger af Salmernes Bog i Det Gamle Testamente, Günter Baders og Paul Ricoeurs. Begge læsninger beskæftiger sig med Guds selvåbenbaring i sit navn og det menneskelige jegs selvpræsentation i en række salmer. Artiklen diskuterer parallellisme og selvforhold i Salmernes Bog i sammenhæng med moderne subjektfilosofi hos Herder og den tyske idealisme, samt i forbindelse med strukturalisme og poststrukturalisme, og den argumenterer for, at Salmernes Bog har været en uerkendt forudsætning for subjektfilosofien, som blev overvundet, hvilket udtrykkes med metaforen "stensalmer".

Jacob P.B. Mortensen undersøger Kants begreb om det radikale onde, der udfoldes i Die Religion innerhalb der Grenzen der blossen Vernunft. Mortensen argumenterer for, at Kant kom til at underminere sit eget fornufts- og frihedsbegreb ved på den ene side at hævde, at friheden er fornuftens kilde og dermed god, men på den anden side netop udledte det radikale onde fra friheden. Dermed tilslutter artiklen sig en marginaliseret strømning i Kant-forskningen, der hævder, at Kants filosofi ender i en selvmodsigende og paradoks position.

Jens Holger Schjørring publicerer sin opposition ved Tine Reehs forsvar for hendes disputats om Hal Koch. Blandt Schjørrings indvendinger kan det fremhæves, at der ifølge ham gives et alt for unuanceret billede af "den dialektiske teologi" som afgørende faktor i Kochs udvikling, samt at Kochs udvikling efter 1932 rummede flere nybrud, specielt efter 1945 .

I en review-artikel anmelder Bo Kristian Holm tre værker, der alle beskæftiger sig med sammenhængen mellem religion og samfundsudvikling: Det første værk hævder, at der var store ligheder i synet på velgørenhed og fromhed inden for kristendom, islam og jødedom i senantikken og middelalderen. I forhold til den udbredte modstilling mellem et religiøst Amerika og et sekulariseret Europa argumenterer det andet værk bl.a. for, at mange sekulariserede europæere stadig ser sig selv som hørende til kirken, men uden at være troende, og at den europæiske velfærdsstat har religiøse rødder. Det tredie værk efterprøver tesen om den lutherske tradition som væsentlig for udviklingen af den danske velfærdsstat. 